\title{
Effect of refrigerated storage on the technological characteristics of meat stick made of insect and pork Alternative burger meat
}

\author{
RICHARD PINTER* (D, EVELIN MOLNAR, KHABAT N. HUSSEIN, \\ ADRIENN TOTH, LASZLO FRIEDRICH and KLARA PASZTOR-HUSZAR
}

Department of Refrigeration and Livestock Products' Technology, Szent István University, Faculty of Food Science, Ménesi út 43-45, H-1118 Budapest, Hungary

\section{CONFERENCE FULL PAPER}

Received: August 13, 2020 - Accepted: September 27, 2020

Published online: November 20, 2020

(c) 2020 The Author(s)

\section{ABSTRACT}

The objective of this study was to research the adaptability of insects in food products. The created hamburger patties were made with pork meat and insect batter (Zophobas morio) in a 50:50 ratio and the color, $\mathrm{pH}$ value, water-holding capacity, roasting loss, texture, microbiological traits were studied during ten days of refrigerated storage $\left(5^{\circ} \mathrm{C}\right.$, vaccum packaging, air cooling). Similar products have already existed in European markets, but these are made of $100 \%$ of insect meat or with additional vegetables as an ingredient. The mixture of insect and pork could offer a more accepted texture by consumers than the other alternatives. This study showed burger patties with pork meat and insect meat offering a softer texture and darker color, while it could increase the shelf-life of raw product.

\section{KEYWORDS}

hamburger patties, entomophagy, insect eating, storage

\footnotetext{
*Corresponding author. E-mail: pinterichard@gmail.com
} 


\section{INTRODUCTION}

In 2050 the population of the Earth will exceed 9 billion, which will result in vastly increased food consumption (Godfray et al., 2010). As a result, the need for animal derived proteins and the demand for higher quality food will also escalate. The yearly meat consumption will rise from 200 billion tons to 470 billion tons, grain consumption will augment from 2.1 billion tons to 3 billion tons. Furthermore, the world's agricultural land use will be higher due to food production purposes (nowadays it is 45\%) (Thornton et al., 2011). The development of modern technologies is pointless, as the growth of the problem is getting unstoppable. Therefore, we need a solution wherewith the agricultural footprint and the industrial waste will be at minimum level, while the food production will keep up with the demand of growing population (Lundqvist et al., 2008). In consequence, we have to change our eating habits. The entomophagy (insect eating) and the developing insect industry could be a solution for the problems or at least it may reduce them. The production of insect based products has several advantages over that of commercial meat products as it requires lower water use (Vogel, 2010), less land use (Zanolli, 2014), lower emission of greenhouse gases (Fiala, 2008)), waste reducing because they can be fed on organic byproducts (Dossey et al., 2016). Moreover, these products are extremely healthy as they have high vitamin and protein content (Bukkens, 1997), have increased amount of essential amino acids and have some minerals and unsaturated fatty acids in high quantity (Finke et al., 1987).

On the other hand, nearly all over Europe and the majority of the world people do not support these ingredients because of religious, social, emotional, and other reasons (Looy et al., 2013) although they have been present since the ancient times (Lesnik, 2011). Researchers should elevate the level of acceptability and should spread more information about the advantages of entomophagy. Most of the studies investigate the edible insects from the point of view of climate change or the sensory aspect. Considering this, we concentrate on the technological benefits of insect usage in food. Alternative insect-based meat products (e.g., Essento, Bugfundation) have already existed in European markets like Switzerland or Germany, but these are made of $100 \%$ of insect meat or with additional vegetables as an ingredient. However, the acceptence of insect-based burgers depends on many factors (e.g., traditions, age, and gender), but the key factors are texture and taste (Harms and Pirolet, 2018). The acceptance could be increase if the non-traditional food ingredients were mixed with traditional foods, to provide consumers the familiar taste (Tan et al., 2017).

\section{MATERIALS AND METHODS}

\section{Materials}

The ingredients consisted of superworms (Zophobas morio) from the Bugs World company in Budapest, Hungary; minced pork meat (with 25.5\% fat content) and yellow onion from SPAR Hungary Commercial Ltd.; garlic powder, ground roman cummin and ground black pepper from Szilasfood Ltd., table salt mixed with nitrite $\left(99.5 \% \mathrm{NaCl}+0.5 \% \mathrm{NaNO}_{2}\right)$, soluprat (tetrasodium-pyrophosphate) and $\mathrm{Na}$-ascorbate from Solvent Commercial House Ltd, Hungary.

\section{Methods}

Samples preparation. The processing of the superworms were started with a $24 \mathrm{~h}$ fasting (without any food source, at $20^{\circ} \mathrm{C}$ ) than a hibernating phase $\left(4^{\circ} \mathrm{C}, 12 \mathrm{~h}\right.$ ). The steaming was 
done in batches $\left(96{ }^{\circ} \mathrm{C}, 200 \mathrm{~g}, 4 \mathrm{~min}\right)$. Superworms were ground with a Moulinex HV6 type meat-grinder $(3,0001 / \mathrm{min})$. In the early stages of product development it became clear that cithin pieces can be quite hard to chew and may have a disturbing effect on the consumer likeability. Due to this, to remove the chitin particles from the part of the samples, a stive ( 0.4 $\mathrm{mm}$ diametrical mesh) was used to passage through the insect batter and get two fractions. This research investigated the following samples: $\mathrm{P}=$ patties made of just pork meat (control sample), $\mathrm{C}=$ patties with insect meat with cithin, $\mathrm{RC}=$ patties with insect mash with reduced cithin content. The recipe of $\mathrm{P}$ samples is the following: $440 \mathrm{~g}$ minced pork meat, $0.42 \% \mathrm{Na}$ ascorbate, $0.34 \%$ soluprat, $1.67 \%$ salt mixed with nitrite, $0.39 \%$ ground black pepper, $0.27 \%$ ground roman cummin, $5.68 \%$ toasted yellow onion, $0.82 \%$ garlic powder. In the case of RC and $\mathrm{C}$ patties half of the pork meat ( $220 \mathrm{~g}$ ) were substituted with the particular type of insect batter $(220 \mathrm{~g})$ and then mixed. After the meat combinations the batters were vacuum packaged. The stored samples were kept at $5{ }^{\circ} \mathrm{C}$. On the measurement days from the packaged meat batter little rectangle shape sticks were formed $(80 \mathrm{~mm} \times 20 \mathrm{~mm} \times 20 \mathrm{~mm}, 20 \mathrm{~g})$. The examined samples were roasted on each measurement day, at $185^{\circ} \mathrm{C}$ for 10 minutes (turning them once) in a fan oven. The tests were performed on the 0 th, the $3 \mathrm{rd}$, the 5 th, the 7 th, and finally the 10 th day.

Water-holding capacity. The water-holding capacity (WHC) was examined according to Grau and Hamm (1953), but the calculation of end-results was different. Due to modernization and the need for higher accuracy results were calculated using AutoCAD 2017 program. The data were calculated from five parallel measurements.

Roasting loss. The sample sticks were measured before and after baking. The roasting loss was calculated with the following formula: roasting loss $(\%)=\left(\left(m_{\text {original }}-m_{\text {roasted }}\right) / m_{\text {original }}\right) \times 100$.

pH. The $\mathrm{pH}$ value was monitored with Testo 206 (Hungary) type digital $\mathrm{pH}$ analyzer performing three repetitions before and after roasting.

Color analysis. Color characteristics of samples was measured using Konica Minolta (Japan) CR 410 type digital colorimeter. The CIE Lab $L^{*}, a^{*}$ and $b^{*}$ values were analyzed with the average of five repetitions before and after roasting, inside and on the surface of the sticks.

Texture. Stable Micro System (United Kingdom) TA.XTplus type device was used to monitor the textural changes during storage, after roasting. Warner-Bratzler head was used (fix counterweight: 50 g, velocity: $2 \mathrm{~mm} / \mathrm{s}$ ). The data were evaluated using Texture Exponent 32 software to determine the maximum penetrational force $(\mathrm{N})$ based on the average of nine replicates.

Microbiological analysis. The aerob mesofil microba count (CFU/g) was analyzed according to the Codex Alimentarius Hungaricus, 1986 3640/4-86 Hungarian standard using TGE agar, with $48 \mathrm{~h}$ incubation period at $30^{\circ} \mathrm{C}$.

Sensory analysis. The roasted samples were analyzed only in a subjective way by the authors, and described by the private opinion.

Statistical analysis. The statistical analysis was carried out with IBM SPSS (United State) statistic 24 software. 


\section{RESULTS AND DISCUSSION}

\section{Water-holding capacity (WHC)}

On the 0th day (Fig. 1.), all of the samples had nearly the same value. This indicated the strength of the evolved protein stucture and that they did not lose a huge amount of moisture due to mechanical effect. However, the WHC of samples made with insects (RC, C) dropped on the 7th day, which marked the disintegration of protein structure. The bonds developed during steaming fell apart and more water was released. In addition, the RC and C sticks had $36 \%$ fat while the $\mathrm{P}$ product had 30\%. Thus, more fat could have become released from RC and C. Furthermore, homogeneity also influenced the end results because the $\mathrm{C}$ sticks did not release as much moisture as RC.

\section{Roasting loss}

The RC and $\mathrm{C}$ samples released almost $10 \%$ less moisture than the $\mathrm{P}$ sticks (Fig. 2.). The RC and C products contained $31.6 \%$ protein (calculation based on the USDA National Nutrient Database), on the other hand, the P sticks had $16.4 \%$ protein (calculated from the minced meat nutritional chart). In consequence, the RC and $\mathrm{C}$ samples created a more durable protein system which could keep moisture inside the structure more effectively.

\section{$\mathrm{pH}$}

According to Fig. 3, the $\mathrm{pH}$ values decreased during storage (from $6.5 \mathrm{pH}$ to $5 \mathrm{pH}$ ). This variation occurred as a result of Lactobacillus bacteria which produces lactic acid in their active state. This acidity was present during the organoleptic test of the hamburger meat sticks. Therefore, roasting did not have a considerable effect on the $\mathrm{pH}$ value.

\section{Water-holding capacity of stored meats}

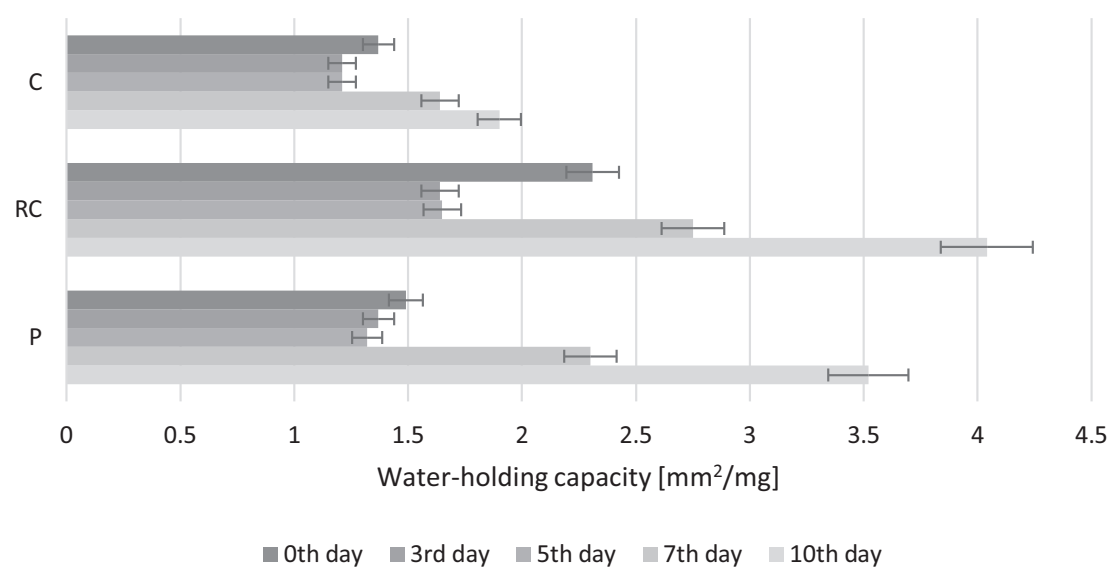

Fig. 1. Water-holding capacity of stored meats $(\mathrm{P}=$ pork, $\mathrm{RC}=$ reduced cithin, $\mathrm{C}=$ with cithin $)$ 


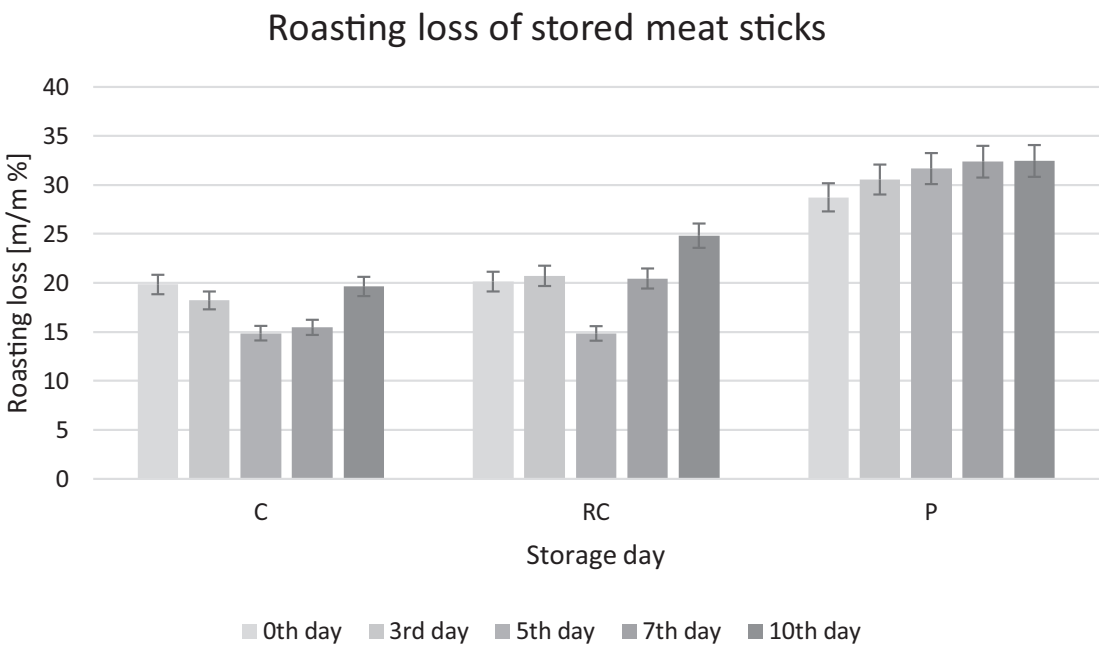

Fig. 2. Roasting loss of stored meat sticks $(\mathrm{P}=$ pork, $\mathrm{RC}=$ reduced cithin, $\mathrm{C}=$ with cithin $)$

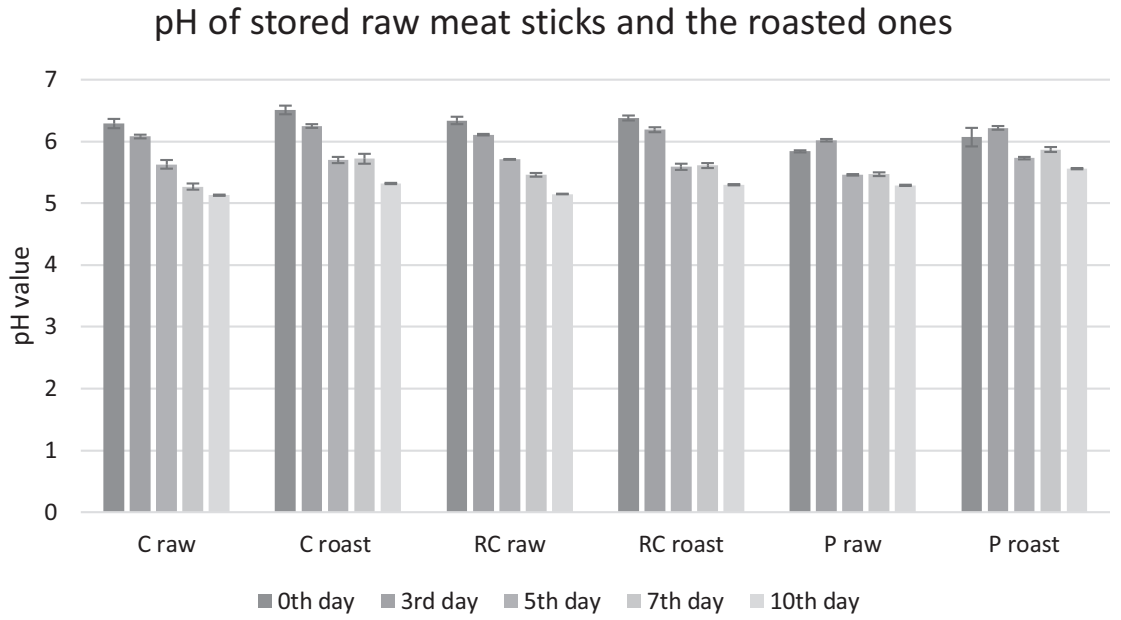

Fig. 3. $\mathrm{pH}$ of stored raw meat sticks and the roasted ones $(\mathrm{P}=$ pork, $\mathrm{RC}=$ reduced cithin, $\mathrm{C}=$ with cithin $)$

\section{Color}

The lightness $\left(L^{*}\right)$ increased in the case of every sample (Fig. 4.). Thus, the samples became lighter with the progress of time. However, this difference was not that outstanding, which proved the effectiveness of vacuum packaging. Moreover, the unroasted RC and C samples had a higher unsaturated fatty acid content as they became darker. In opposition, the roasted sticks were lighter with ten units. The color of the surface was darker compared the cutting surface. This variation also appeared in the values of $a^{*}$ and $b^{*}$. 
$L^{*}$ value of the stored meat sticks and the roasted ones on the surface (S) and on the cutting surface (I)

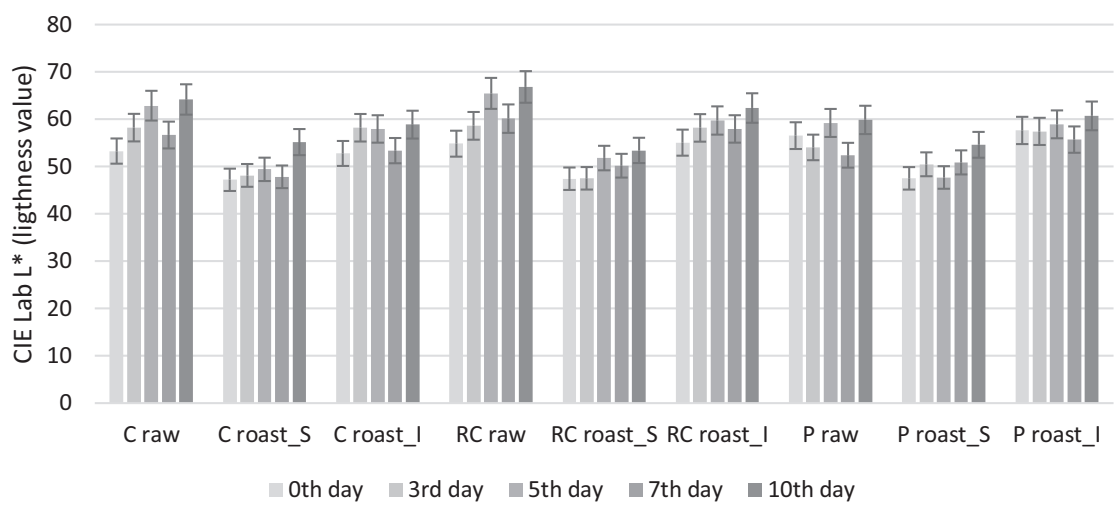

Fig. 4. $L^{*}$ value of the stored meat sticks and the roasted ones on the surface $(S)$ and on the cutting surface $(I)$

\section{Texture}

The maximum penetration force (Fig. 5) refers to the force of biting through the sticks. RC needed the least amount of force as it was the softest and most homogeneous sample (as also detected by tasting the sticks). C needed nearly two times more power to penetrate through due to the presence of cithin pieces. On the contrary, the P samples needed the most force to penetrate because of the sinewy parts of the pork meat. This dense structure also appeared during sensory test as they were drier and less juicy.

Penetration force of the roasted meat sticks during the storage period

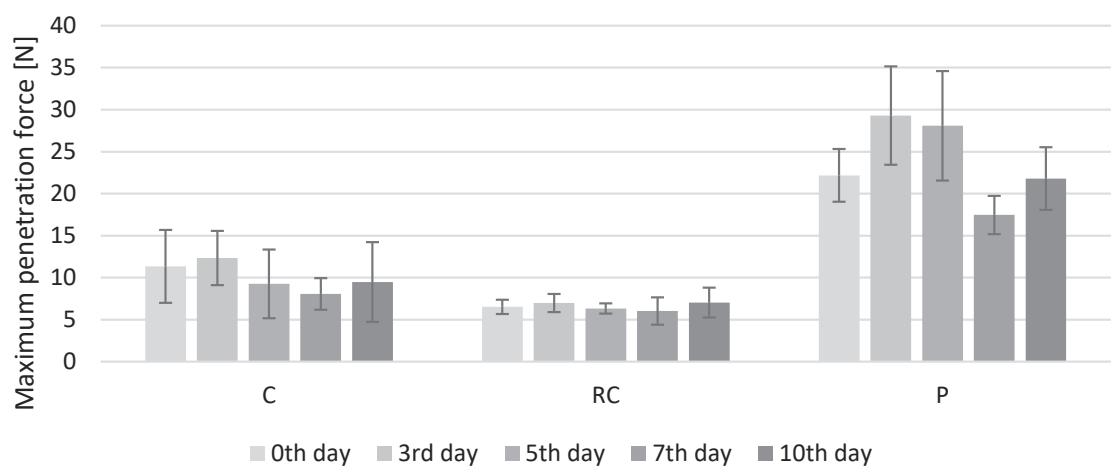

Fig. 5. Penetration force of the roasted meat sticks during the storage period 


\section{Microbiological analysis}

Initially, all the samples contained $10^{4} \mathrm{CFU} / \mathrm{g}$ (Fig. 6) aerobic mesophilic microba. According to the 4/1998. (XI. 11.) EüM Hungarian regulation the accepted level of microba count in minced meat is maximum $10^{7} \mathrm{CFU} / \mathrm{g}$. Regarding this the unroasted $\mathrm{P}$ sample reached this limit on the 6th day but the RC and $\mathrm{C}$ sticks reached it on the 7th. Therefore, the durability of the insectbased product was longer by one day. It is also noticeable that roasting was effective in all cases although the $\mathrm{C}$ sticks had less microbes with nearly 20,000 CFU/g due to the antifungicide and antibacterial traits of cithin. One-way ANOVA analysis also proved this $(\alpha=0.05)$ : $\mathrm{C}$ and $\mathrm{P}$ : $P=0.0396$ (significant), $\mathrm{C}$ and RC: $P=0.0284$ (significant), RC and $\mathrm{P}: P=0.9017$ (not significant).

\section{CONCLUSION}

During the refrigerated storage the $\mathrm{pH}$ value decreased. The colors of the samples became darker after roasting and darker with the progression of time, which might be related to the high ratio of monounsaturated fatty acids in Z. morio (Ramos et al., 2016). During refrigerated storage the $100 \%$ pork sticks had lower loss of moisture then the others. On the other hand, the C and RC meat sticks had less roasting loss then the pork meat sticks. It means that precooking (steaming) was not effective enough to prevent the loss of moisture during refrigerated storage in samples with insect. Contrary, roasting was effective to improve the retention of moisture in samples with insect. The water-holding capacity of $\mathrm{C}$ and $\mathrm{RC}$ declined to a greater extent than that of $\mathrm{P}$ during storage as the proteins structure disintegrated. This can be improved with a higher dosage of tetrasodium-pyrophosphate. During the texture analyses the heterogeneity of the C product had an important effect on the biting but the $\mathrm{P}$ sticks had the highest maximum

\section{Aerob mesophilic microba count of stored raw meat} sticks and after roasting

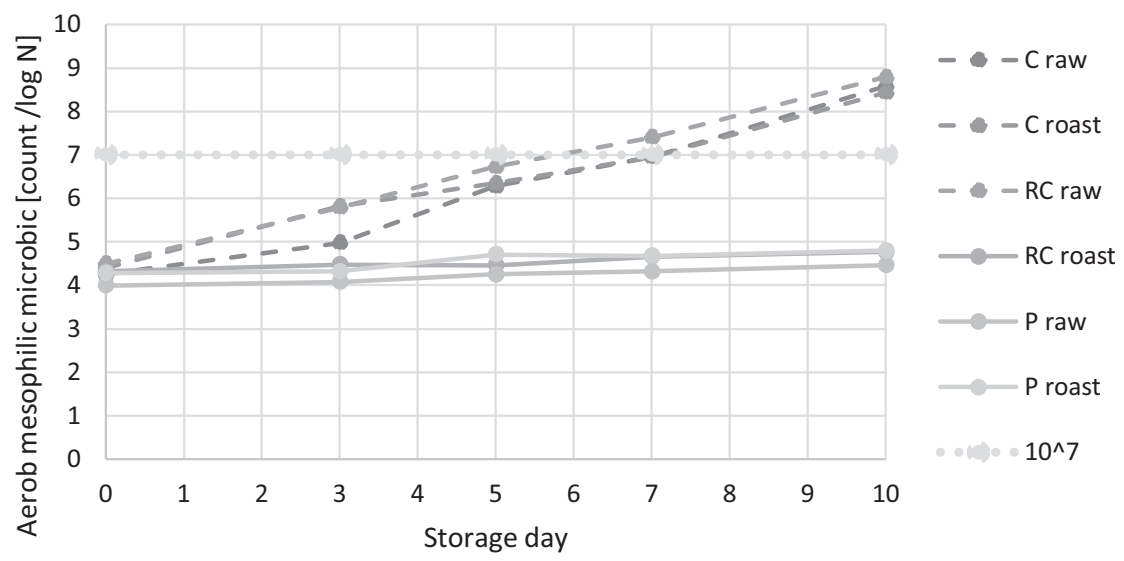

Fig. 6. Aerob mesofil microba count during storage 
penetration force because of the sinews. RC was the softest while $\mathrm{P}$ was found to be the hardest. Lastly, the aerob mezophilic microba counts of unroasted sticks increased with the same tendency, but the RC and $\mathrm{C}$ were consumable for one more day because of their precooked state. After roasting the antimicrobial traits of cithin were imminent as $\mathrm{C}$ sticks had significantly lower microba count.

Previous study showed that the chitosan has a positive effect on the pork meat-based products. The high molecular weight chitosan improves cooking characteristics and antioxidant activity in vitro, low molecular weight chitosan extends red color and reduces total viable counts. The results of texture analysis suggested that the cohesiveness and brightness of chitosan containing burgers' increased during storage (Sayas-Barberá et al., 2011). The results obtained showed similarities in cooking characteristics and brightness, despite the samples we investigated also contained chitin and insect meat after grinding as well. Even as we created a fraction with a lower chitin content, it also contained some chitin both insect sticks samples. However, these results require more investigation.

The oxidative process in meat products with high ratio of unsaturated fatty acids lead to intensive degradation, which contributed to the deterioration in color, texture and flavor (Zanardi et al., 2002).

Due to the high MUFA content of Z. morio it has possible uses in the food industry. The presence of olic acid gives favorable textural properties and it is commonly used as emulsifying agent and food additive. On the other hand, the lower cholesterol content could offer further potential, especially for the meat industry (Ramos et al., 2016).

In the course of this study, many advantages and a few disadvantages of the insect-based hamburger sticks were revealed. Therefore, this topic needs more research. Our results contributed to the usability of insect ingredients in the food industry, and it could be a starting point for further development to increase consumer acceptance, thereby reducing the ecological footprint of the food industry with insect-based functional foods.

\section{ACKNOWLEDGEMENTS}

The project was supported by the European Union and co-financed by the European Social Fund (grant agreement no. EFOP-3.6.3-VEKOP-16-2017-00005)." The authors would like to thank the laboratory technician colleagues and the Doctoral School of Food Sciences - SZIU Hungary for their support in conducting this research.

\section{REFERENCES}

Bukkens, S.G.F. (1997). The nutritional value of edible insects. Ecology of Food Nutrition, 36: 287-319. Codex Alimentarius Hungaricus, (1986). MSZ 3640/4 - 86. Microbiological examination of meats and meat - based foods. Determination of the most probable number of aerobic microbes in a liquid medium. Hungarian Standards Board, Hungary.

Dossey, A., Tatum, J., and McGill, W. (2016). Chapter 5: Modern insect-based food industry: current status, insect processing technology, and recommendations moving forward. In: Dossey, A., Morales-Ramos, J., and Rojas, M. (Eds.), Insects as sustainable food ingredients, Elsevier, pp. 122-145. 
Fiala, N. (2008). Meeting the demand: an estimation of potential future greenhouse gas emissions from meat production. Ecological Economics, 67: 412-419.

Finke, M.D., DeFoliart, G.R., and Benevenga, N.J. (1987). Use of a four-parameter logistic model to evaluate the protein quality of mixtures of Mormon cricket meal and corn gluten meal in rats. Journal of Nutrition, 117: 1740-1750.

Godfray, H.C.J., Beddington, J.R., Crute, I.R., and Haddad, L. (2010). Food security: the challenge of feeding 9 billion people. Science, 327: 812-818.

Grau, R., and Hamm, G. (1953). Eine Einfache Methode zur Bestimmung der Wasserbindung in Muskel. Die Naturwissenschaften, 40(1): 259-277.

Harms, E. and Pirolet, N. (2018). Consumer acceptance of insect-based burgers. Appetite, 130: 306.

Lesnik, J.J. (2011). Bone tool texture analysis and the role of termites in the diet of South African hominids. PaleoAnthropology, 268: 281.

Looy, H., Dunkel, F.V., and Wood, J.R. (2013). How then shall we eat? Insect-eating attitudes and sustainable foodways. Agriculture and Human Values, 31: 131-141.

Lundqvist, J., De Fraiture, C., and Molden, D. (2008). Saving water: from field to fork: curbing losses and wastage in the food chain. Stockholm International Water Institute. Policy paper, Working brief, pp. $20-23$.

Ramos-Bueno, R.P., González-Fernández, M.J., Sánchez-Muros-Lozano, M.J., García-Barroso, F., and Guil-Guerrero, J.L. (2016). Fatty acid profiles and cholesterol content of seven insect species assessed by several extraction systems. European Food Research and Technology, 242(9).

Sayas-Barberá, E., Quesada, J., Sánchez-Zapata, E., Viuda-Martos, M., Fernández-López, F., Pérez-Alvarez, J.A., and Sendra, E. (2011). Effect of the molecular weight and concentration of chitosan in pork model burgers. Meat Science, 88(4): 740-749.

Tan, H.S.G., Tibboel, C.J., and Stieger, M. (2017). Why do unusual novel foods like insects lack sensory appeal? Investigating the underlying sensory perceptions. Food Quality and Preference, 60: 48-58.

Thornton, P., Herrero, M., and Ericksen, P. (2011). Livestock and climate change. ILRI. Available from: http://go.nature.com/wYaVA6.

Vogel, G. (2010). For more protein, filet of cricket. Science, 327(5967): 811.

Zanardi, E., Dorigoni, V., Badiani, A., and Chizzolini, R. (2002). Lipid and colour stability of Milano- type sausages: effect of packing conditions. Meat Science, 61: 7-14.

Zanolli, L. (2014). Insect farming is taking shape as demand for animal feed rises. Available from: http:// www.technologyreview.com/news/529756/insectfarming-is-taking-shapte-as-demand-for-animinalfeed-rises4/1998. (XI. 11.) EüM Decree (1998) on the permissible level of microbiological contaminants in foodstuffs.

Open Access. This is an open-access article distributed under the terms of the Creative Commons Attribution 4.0 International License (https://creativecommons.org/licenses/by/4.0/), which permits unrestricted use, distribution, and reproduction in any medium, provided the original author and source are credited, a link to the CC License is provided, and changes - if any - are indicated. (SID_1) 